\title{
Murine BAFF expression is up-regulated by estrogen and interferons: Implications for sex bias in the development of autoimmunity
}

\author{
Ravichandran Panchanathan ${ }^{1,2}$ and Divaker Choubey ${ }^{1,2}$ \\ ${ }^{1}$ Department of Environmental Health, University of Cincinnati, 3223 Eden Avenue, P. O. \\ Box-670056, Cincinnati, OH 45267 \\ ${ }^{2}$ Cincinnati VA Medical Center, 3200 Vine Street, Cincinnati, OH 45220
}

\begin{abstract}
Systemic lupus erythematosus (SLE) in patients and certain mouse models exhibits a strong sex bias. Additionally, in most patients, increased serum levels of type I interferon (IFN-a) are associated with severity of the disease. Because increased levels of B cell activating factor (BAFF) in SLE patients and mouse models are associated with the development of SLE, we investigated whether the female sex hormone estrogen (E2) and/or IFNs (IFN-a or $\gamma$ ) could regulate the expression of murine BAFF. We found that steady-state levels of BAFF mRNA and protein were measurably higher in immune cells $\left(\mathrm{CD} 11 \mathrm{~b}^{+}, \mathrm{CD} 11 \mathrm{c}^{+}\right.$, and CD19+) isolated from C57BL/6 females than the age-matched male mice. Treatment of immune cells with IFN or E2 significantly increased levels of BAFF mRNA and protein and a deficiency of estrogen receptor-a, IRF5, or STAT1 expression in splenic cells decreased expression of BAFF. Moreover, treatment of RAW264.7 macrophage cells with IFN-a, IFN- $\gamma$, or E2 induced expression of BAFF. Interestingly, increased expression of p202, an IFN and estrogen-inducible protein, in RAW264.7 cells significantly increased the expression levels of BAFF and also stimulated the activity of the BAFF-luc-reporter. Accordingly, the increased expression of the p202 protein in lupus-prone B6.Nba2-ABC than non lupus-prone C57BL/6 and B6.Nba2-C female mice was associated with increased expression levels of BAFF. Together, our observations demonstrated that estrogen and IFN-induced increased levels of the p202 protein in immune cells contribute to sex bias in part through up-regulation of BAFF expression.
\end{abstract}

\section{Keywords}

BAFF; estrogen; interferon; p202; SLE

C 2012 Elsevier Ltd. All rights reserved.

Address Correspondence to: Divaker Choubey, Department of Environmental Health, University of Cincinnati, 3223 Eden Avenue, P.O. Box 670056, Cincinnati, OH 45267; Ph.: 513-558-1014, Fax: 513-558-0925, Divaker.choubey@uc.edu.

Publisher's Disclaimer: This is a PDF file of an unedited manuscript that has been accepted for publication. As a service to our customers we are providing this early version of the manuscript. The manuscript will undergo copyediting, typesetting, and review of the resulting proof before it is published in its final citable form. Please note that during the production process errors may be discovered which could affect the content, and all legal disclaimers that apply to the journal pertain.

Conflicts of interest

Authors declare no conflict of interest. 


\section{Introduction}

Systemic lupus erythematosus (SLE) is a complex autoimmune disease, which is characterized by the production of pathogenic autoantibodies against certain nuclear antigens and DNA [1,2]. The disease has potential to involve multiple organs and tissues. SLE in patients and certain mouse models exhibits a strong sex bias (develops at a femaleto-male ratio of 9:1) [3-5]. Additionally, most patients also exhibit increased serum levels of type I interferon (IFN- $\alpha$ ), activation of IFN-inducible genes (the "IFN-signature"), and systemic and localized inflammation $(2,6)$. In particular, inflammation-associated damage to kidneys presents a serious challenge in treating SLE patients [2].

The B cell-activating factor (BAFF; also called BLyS) is a member of the TNF-family of proteins [7-9]. Expression of BAFF is detectable in a variety of cell types [10-12]. However, it is primarily expressed by macrophages and DCs [7, 9]. BAFF activates the classical and the non-canonical NF- $\kappa \mathrm{B}$ signaling in B cells that stimulates the expression of a set of genes that are essential for B cell survival and differentiation [13]. Additionally, BAFF also enhances the survival of plasmablasts and stimulates peripheral B cell proliferation, Ab production, and class switching through an induction of activation induced deaminase (AID) [8, 9]. Homozygous deletion of the BAFF-encoding Tnfsf13b gene in mice interferes with B cell development at the stage of transitional B cells [14]. In contrast, overexpression of BAFF in mice induces autoimmunity [15]. Accordingly, transgenic (Tg) mice that overproduce BAFF develop severe autoimmune disorders that resemble systemic lupus erythematosus and Sjögren's syndrome [16]. Interestingly, exposure of young lupusprone $(\mathrm{NZB} \times \mathrm{NZW}) \mathrm{F}_{1}$ mice with IFN-a, which accelerates autoimmunity, is associated with increased serum levels of BAFF and IL-6 [17]. Increased serum levels of BAFF have also been noted in patients suffering from certain autoimmune diseases, including rheumatoid arthritis, Sjögren's syndrome, and SLE [18]. However, signaling pathways that contribute to increased expression of BAFF in SLE patients and certain mouse models remain largely unknown. Notably, an inhibition of BAFF/BAFF-R interactions by antibodies to BAFF has been found to be effective in reducing disease activity in a sub-set of SLE patients [19]. Consequently, anti-BAFF therapy has recently been approved for SLE treatment.

Mouse models of lupus diseases have contributed to our overall understanding of the molecular mechanisms that contribute to the development of lupus disease [20, 21]. These models include the $F_{1}$ hybrid of the New Zealand Black (NZB) and New Zealand White (NZW) strains. Generation of B6.Nba2 congenic (congenic for the NZB-derived Nba2 interval on the C57BL/6 genetic background) mice indicated that these mice exhibit sex bias in the development of antinuclear autoantibodies (ANAs) [22, 23] and type I IFN-signaling contributes to the lupus phenotype [24]. Therefore, the B6.Nba2 congenic mice have been used to investigate the molecular mechanisms through which the sex hormones and the IFNsignaling may contribute to the development of lupus [25-27].

The Nba2 interval ( 90-97 cM), which is located on the distal portion of the NZB chromosome 1, has emerged as a major genetic contribution to the disease susceptibility in the $(\mathrm{NZB} \times \mathrm{NZW}) \mathrm{F}_{1}$ mice [22, 25-27]. The interval, which is syntenic to human lupus susceptibility region 1q, contains genes that encode for the $\mathrm{Fc} \gamma$ receptors (including the Fc $\gamma$ RIIB inhibitory receptor, which is encoded by the $F c g r 2 b$ gene), Slam/CD2 family proteins, and p200-family proteins (encoded by the Ifi200-family genes) [26, 27]. Interestingly, the generation of sub-congenic mouse lines of the $N b a 2$ interval and generation of $F c g r 2 b$ and Aim2 (encoding for the Aim2 protein, a member of the p200family) deficient mice have provided evidence that epistatic interactions between the Ifi200- 
family genes and other $\mathrm{Nba2}$ genes such as the $F c g r 2 b$ gene may contribute to the modification of lupus phenotype [28-31].

Increased expression levels of the p202 protein (encoded by the Ifi202 gene) in a variety of mouse models of lupus are associated with lupus phenotype [26]. Interestingly, expression of Ifi202 gene is up-regulated by sex hormone estrogen through estrogen receptor-a (ERa) and type I IFN $[32,33]$. Increased nuclear levels of the p202 protein in immune cells modulate the transcriptional activity of a number of factors, including NF- $\mathrm{BB}, \mathrm{AP}-1, \mathrm{E} 2 \mathrm{Fs}$, and p53 in a cell type-dependent manner [25, 26]. Additionally, increased expression of p202 protein in macrophage cell lines also activates the type I IFN responses and induces the expression of type I IFN [31]. However, the molecular mechanisms through which the p202 protein contributes to the ANA phenotype in the B6.Nba2 mice remain unclear.

Studies have implicated regulation of BAFF expression by interferons and estrogen-induced signaling [34-36]. However, the molecular mechanisms remain unknown. Given that a mutually positive regulatory loop between type I IFN-signaling and ERa regulates the expression of the IFN and estrogen regulated genes [37] and increased serum levels of BAFF in SLE patients and certain mouse models are associated with SLE phenotype [1518], we investigated the molecular mechanisms through which expression of murine BAFF is up-regulated by IFNs and estrogen. Here we report that estrogen and IFN-induced signaling, which up-regulates the expression of p202, contributes to increased expression of murine BAFF.

\section{Materials and methods}

\subsection{Mice, splenic cells, and treatments}

The University of Cincinnati's Animal Care and Use Committee approved the experimental protocols for the experiments involving mice. Male and female C57BL/6J, MRL, MRL-lpr/ lpr, and B6.Nba2 mice (mice age-matched; 8-9 weeks old) were purchased from The Jackson Laboratory. Stat1-deficient (mice on the 129S6 genetic background) mice and the corresponding wild-type mice were purchased from Taconic Farms (Germantown, NY). Mice were housed in a specific pathogen-free Laboratory of Animal and Medical Services facility at the University of Cincinnati. Dr. Karen Gould (University of Nebraska Medical Center, Omaha, NE) provided spleens from wild type and ERa-deficient $(\mathrm{NZB} \times \mathrm{NZW}) \mathrm{F}_{1}$ mice [32]. Dr. Loren Erickson (University of Virginia, Charlottesville, VA) provided spleens from control (C57BL/6) and B6.Nba2-ABC and B6.Nba2-C mice [31]. Dr. Paula Pitha (The Johns Hopkins University, Baltimore, MD) provided spleens from the Irf5deficient mice [38].

Total spleen cells or bone marrow-derived cells were prepared from male or female agematched mice as described by us previously [31]. Cells were suspended in RPMI-1640 medium (supplemented with $10 \%$ fetal bovine serum and antibiotics). Cells from two or

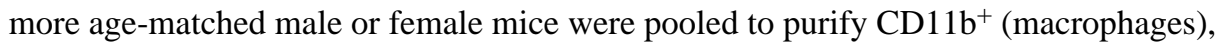
$\mathrm{CD} 11 \mathrm{c}^{+}$(dendritic cells) and B220 $0^{+}$or $\mathrm{CD} 19^{+}$(B cells) immune cells. Pooled cells were purified using magnetic MicroBeads (purchased from Miltenayi Biotech, Auburn, CA) allowing the positive selection of the indicated cells. The purified (>90-95\% pure) cells were used immediately for further experiments. Cultures of CD11 $\mathrm{b}^{+}$cells were supplemented with macrophage colony stimulating factor $(10 \mathrm{ng} / \mathrm{ml})$.

For treatment of cells with the female sex hormone $17 \beta$-estradiol (E2), cells were cultured in phenol red-free DMEM medium (Invitrogen, Carlsbad, CA). To minimize levels of steroid hormones in the medium, the medium was supplemented with $10 \%$ charcoal-stripped fetal 
bovine serum (Invitrogen). Cells in culture were treated with E2 at the indicated concentrations.

\subsection{Macrophage cell lines, treatments, and p202 expression}

RAW264.7 cells (purchased from the American Type Culture Collection, Manassas, VA) were maintained in culture as suggested by the supplier. Sub-confluent cultures of cells were treated with E2 in phenol-free medium as described above, IFN-a $(1,000 \mathrm{u} / \mathrm{ml}$; IFN from PBL Biomedical Laboratories, Piscataway, NJ) or IFN- $\gamma(10 \mathrm{ng} / \mathrm{ml})$ as described above.

To overexpress p202 protein, sub-confluent cultures of cells (in a 6-well plate) were transfected with an empty vector (pCMV) or p202 expression plasmid (pCMV-202) using FuGENE 6 transfection reagent (Roche Applied, Indianapolis, IN) as suggested by the supplier. The transfected cells were selected in G418 (400 $\mu \mathrm{g} / \mathrm{ml})$ for two weeks. The G418resistant colonies were pooled and pooled cells were analyzed for overexpression of p202 and BAFF.

To knock down the expression of p202 in J774.A1 cells (cells purchased from ATCC), cells in a 6-well plate were either infected with lentivirus (purchased from Santa Cruz Biotechnology, Santa Cruz, CA) encoding short hairpin RNA (shRNA) to Ifi202 (sc-40698V) genes or a control shRNA (sc-108080). After infections, cells were selected in puromycin $(1 \mu \mathrm{g} / \mathrm{ml})$ for $\sim$ week. Puromycin-resistant cells were pooled and analyzed for the expression of p202 and BAFF.

\subsection{Isolation of RNA from splenocytes and PCR}

Total RNA was isolated from freshly prepared splenocytes $\left(5-8 \times 10^{6}\right.$ cells) using TRIzol (Invitrogen) isolation method. To remove any contaminating genomic DNA in RNA preparations, RNA preparation was digested with DNase I. The digested RNA preparation containing $0.5-2 \mu \mathrm{g}$ of RNA was used for reverse transcriptase (RT) reaction. We performed quantitative real-time TaqMan PCR using 7300 Real-Time PCR System TaqMan gene expression assays (Applied Biosystems, Foster City, CA) as described previously [31]. The TaqMan assays were: murine Tnfsf13b (or Baff; Assay Id\# Mm00446347_m1) and the endogenous control $\beta 2$-microglobulin (Assay Id\# Mm00437762_m1). For the regular PCR the following primer pair was used to amplify murine BAFF cDNA (fragment length 347bp): forward primer: 5'-TGTTGTCCAGCAGTTTCAC-3'; backward primer: 5'CTGCAG ACAG TCTTGAATGA-3'.

\subsection{Immunoblotting}

Purified indicated immune cells were lysed in a modified radio-immune precipitation assay (RIPA) lysis buffer (50 mM Tris-HCl, pH 8.0, $250 \mathrm{mM} \mathrm{NaCl}, 1 \%$ Nonidet P-40, 0.5\% sodium deoxycholate, $0.1 \%$ SDS). The buffer was supplemented with $1 \mathrm{X}$ protease inhibitor (Roche Diagnostics, Mannheim, Germany). Lysates were incubated at $4^{\circ} \mathrm{C}$ for $30 \mathrm{~min}$. Cell lysates were briefly sonicated, centrifuged (at $14,000 \mathrm{rpm}$ for $10 \mathrm{~min}$ at $4^{\circ} \mathrm{C}$ ), and the supernatants were collected. Cell lysates containing approximately equal amounts of total proteins were subjected to immunoblotting using the indicated antibodies. Antibodies to murine BAFF were purchased from Abcam (Cambridge, MA; Cat \#ab8396). Antibodies to actin (cat \# 5125) were purchased from Cell Signaling Technology (Danvers, MA). Polyclonal antibodies to p202 and Aim2 proteins that were raised by us in rabbits have been described previously [31].

\section{5. Reporter assays}

Sub-confluent cultures of RAW264.7 cells (in a six-well plate) were transfected with the reporter plasmids BAFF-Luc (1.0 $\mu \mathrm{g}$; the reporter plasmid generously provided by Dr. 
Pyeung-Hyeun Kim, Kangwon National University, Republic of Korea, ref. 39) and pRLTK $(0.2 \mu \mathrm{g})$ along with either an empty vector $\mathrm{pCMV}(0.8 \mu \mathrm{g})$ or equal amounts of a plasmid that allowed the expression of murine p202 (pCMV-202) using the FuGENE 6 (Roche Applied Science, Indianapolis, IN) transfection reagent as suggested by the supplier. Cells were harvested between 40 and $45 \mathrm{~h}$ after transfections, and the firefly and Renilla dual luciferase activities were determined [31].

\section{6. Statistical analyses}

The experimental values were presented as means \pm SEM. The statistical significance was calculated using Student's two-tailed $t$ test. A $P$ value of $<0.05$ was considered significant.

\section{Results}

\subsection{Gender, sex hormone estrogen, and IFN increase BAFF mRNA levels}

Various cell types are reported to express detectable levels of BAFF mRNA and protein [9]. Therefore, to investigate regulation of BAFF levels in immune cells, we compared steadystate levels of BAFF mRNA in purified populations of splenic $\mathrm{CD}^{+}$(T cells) or B220 $0^{+}$B cells) cells and bone marrow-derived $\mathrm{CD}_{11} \mathrm{~b}^{+}$(macrophages) or $\mathrm{CD} 11 \mathrm{c}^{+}$(dendritic cells) cells that were isolated from $\sim 9$-week-old C57BL/6 male or female mice. As shown in Fig. $1 \mathrm{~A}$, we were able to detect expression of BAFF mRNA in all cell types analyzed. However, levels were much higher in $\mathrm{CD} 11 \mathrm{~b}^{+}$and $\mathrm{CD} 11 \mathrm{c}^{+}$cell populations. Interestingly, the levels of the BAFF mRNA were measurably higher in cells isolated from females than males. Accordingly, constitutive (compare lane 4 with 1 ) and induced (induced by IFN-a or E2) levels of BAFF protein were appreciably higher in extracts from $\mathrm{CD} 11 \mathrm{c}^{+}$cells isolated from female mice than the age-matched males (Fig. 1B). Moreover, treatment of splenic B220 $0^{+}$ cells with IFN-a or E2 also increased levels of BAFF mRNA (Fig. 1C) and protein (Fig. 1D) 2-3-fold. Together, these observations suggested that the constitutive and induced (induced by IFN-a or E2) expression levels of BAFF depend on factors such as gender, estrogen, and type I IFN.

\subsection{Expression of BAFF depends on ERa, IRF5, and STAT1}

Our above observations that treatment of $\mathrm{CD} 11 \mathrm{c}^{+}$and $\mathrm{B} 220^{+}$cells with either estrogen or IFN- $a$ increased level of BAFF (Fig. 1) prompted use to investigate whether deficiency of estrogen receptor- $a$ or modulators of type I IFN responses, such as IRF5 or STAT1, could affect expression levels of BAFF. As shown in Fig. 2A, steady-state levels of BAFF mRNA were 30-40\% lower in splenic cells isolated from Esr1-deficient than age-matched wild type $(\mathrm{NZB} \times \mathrm{NZW}) \mathrm{F}_{1}$ females. Moreover, a deficiency of IRF5 in splenic cells significantly reduced levels of BAFF (Fig. 2B). Furthermore, in splenic cells from STAT1-deficient male and female mice, levels of BAFF mRNA (Fig. 2C) and protein (Fig. 2D) were appreciably lower than age and gender-matched wild-type mice. Together, these observations revealed that expression of BAFF in immune cells that we tested depends on expression of ERa, IRF5, and STAT1.

\subsection{Treatment of RAW264.7 cells with IFNs or estrogen increases BAFF levels}

To identify the molecular mechanisms through which treatment of immune cells with type I IFN or E2 increases the expression levels of BAFF, we first investigated whether treatment of macrophage cell line RAW264.7 with IFNs (IFN- $a$ or $\gamma$ ) or estrogen could regulate BAFF. As shown in Fig. 3A, treatment of cells with IFN-a or $\gamma$ significantly increased steady-state levels of BAFF mRNA. Moreover, treatment of cells, which were transfected with the BAFF-luc-reporter (expression of the reporter gene driven by the murine Baff promoter), with IFN-a or $\gamma$ also stimulated the activity of reporter appreciably (Fig. 3B). 
Accordingly, treatment of cells with IFN- $a$ or $\gamma$ also resulted in increases in BAFF protein levels (Fig. 3C). Furthermore, treatment of cells with E2 increased levels of BAFF mRNA (Fig. 3D). Together, these observations indicated that activation of IFN or E2-signialing in RAW264.7 cells stimulates expression levels of BAFF.

\section{4. p202 protein up-regulates BAFF expression}

Our above observations that activation of IFN or E2 signaling in RAW264.7 cells increases levels of BAFF encouraged us to explore whether IFN and E2-inducible p202, a lupus susceptibility modifier protein [30], could regulate expression of BAFF. Therefore, cells were nucleofected with pCMV or pCMV-202 expression vector. As shown in Fig. 4, the nucleofection of cells with the pCMV-202 plasmid increased levels of BAFF mRNA (Fig. 4A) and protein (Fig. 4B). Additionally, transfection of cells with pCMV-202, but not pCMV, expression vector also stimulated the activity of the BAFF-luc-reporter (Fig. 4C). Accordingly, knockdown of p202 expression in J774.A1 cells decreased steady-state levels of BAFF protein (Fig. 4D). Together, these observations indicated that increased levels of p202 protein in RAW264.7 cells increase levels of BAFF mRNA and protein.

\subsection{Increased levels of p202 protein in lupus-prone mice are associated with increased levels of BAFF}

Our above observations that overexpression of p202 protein in RAW264.7 cells increased levels of BAFF prompted us to investigate whether expression levels of p202 in immune cells in mice are correlated with expression levels of BAFF. As shown in Fig. 5A, the expression levels of $\mathrm{p} 202$ protein in $\mathrm{CD} 11 \mathrm{c}^{+}$cells isolated from C57BL/6 and B6.Nba2 mice were correlated with BAFF protein levels. Similarly, increased levels of the p202 protein in $\mathrm{CD} 19^{+}$cells isolated from B6.Nba2 as compared to C57BL/6 females were correlated with increased levels of BAFF protein (Fig. 5B). Because non lupus-prone C57BL/6 and B6.Nba2-C (sub-congenic mice), and lupus-prone B6.Nba2 females differ with respect to p202 expression [31], we also compared levels of BAFF mRNA (Fig. 5C) and protein (Fig. 5D) among these strains of mice. Interestingly, increased expression of p202 in lupus-prone strain was associated with increased BAFF levels. Additionally, we also compared expression levels of both $\mathrm{p} 202$ and BAFF proteins between non lupus prone MRL and lupus-prone MRL-Ipr/Ipr male and female mice [40]. As shown in Fig. 5E, increased levels of p202 in lupus-prone MRL-Ipr/lpr mice also associated with increased BAFF levels. Interestingly, these mice did not exhibit any appreciable sex bias in expression of p202 and BAFF (compare lane 2 with 4). Together, these observations revealed that increased levels of p202 protein in lupus-prone mice are associated with increased levels of BAFF.

\subsection{Treatment of cells with BAFF increases expression levels of p202}

Our above observations that increased levels of estrogen and IFN-inducible p202 protein upregulated the expression of BAFF encouraged us to explore whether BAFF could regulate expression of p202. As shown in Fig. 6, treatment of splenic cells isolated from male or agematched female B6.Nba2 mice with recombinant BAFF increased levels of ERa and p202. Because p202 down-regulates the expression of Aim2 protein [41], we also tested levels of Aim 2 protein. We found that BAFF treatment, which increased levels of $\mathrm{p} 202$, reduced levels of Aim2 protein. Together, these observations support the idea that increased levels of BAFF in mice up-regulate expression of p202.

\section{Discussion}

SLE in patients and certain mouse models exhibits a strong sex bias (develops at a femaleto-male ratio of 9:1) [3-5]. Moreover, most SLE patients also exhibit increased serum levels of IFN-a [6]. Therefore, our observations that: (i) BAFF mRNA levels depend on gender, 
levels of sex hormone estrogen and IFNs (Fig. 1); (ii) expression of BAFF depends on ERa, IRF5, and STAT1 expression (Fig. 2); (iii) treatment of RAW264.7 cells with IFNs or estrogen increases BAFF expression levels (Fig. 3); (iv) increased levels of p202 protein upregulates BAFF expression, whereas knockdown of p202 expression decreases BAFF levels (Fig. 4); (v) increased levels of p202 protein in lupus-prone female mice are associated with increased levels of BAFF (Fig. 5); and (vi) treatment of immune cells with BAFF increases levels of p202 protein (Fig. 6) demonstrate that estrogen and IFN-inducible p202 protein and BAFF are likely to be part of a mutually positive regulatory loop. Thus, activation of type I IFN-signaling or estrogen-signaling in immune cells is likely to activate this feedforward loop through up-regulation of p202 and BAFF. In turn, increased levels of BAFF contribute to a sex bias in the development of murine lupus.

Our observations (Fig. 1) that steady-state levels of BAFF mRNA in immune cells (B220+ or $\mathrm{CD} 19^{+}, \mathrm{CD} 11 \mathrm{~b}^{+}$, and $\mathrm{CD} 11 \mathrm{c}^{+}$cells) isolated from C57BL/6 females than age-matched males were higher are consistent with the idea that increases in the levels of the mRNA are dependent upon sex hormones. Accordingly, treatment of immune cells in culture with E2 increased levels of BAFF mRNA and protein (Fig. 1).

ERa-deficiency in lupus-prone $(\mathrm{NZB} \times \mathrm{NZW}) \mathrm{F}_{1}$ female mice reduces glomerulonephritis and increases their survival [42]. Moreover, the deficiency in female mice also retards the development of anti-histone/DNA antibodies. Given that steady-state levels of BAFF mRNA were reduced in the Esr1-deficient splenic cells as compared to wild-type agematched females (Figure 2), our observations are consistent with the idea that activation of $\mathrm{ERa}$ in females contributes to sex bias in autoimmunity through up-regulation of BAFF expression. Further work is in progress to test this possibility.

The BAFF-knockout mice exhibit defects in the development and survival of B2 and marginal zone B cells [14]. Moreover, BAFF transgenic mice that overexpress BAFF develop autoimmunity [15]. Therefore, our observations that $\mathrm{p} 202$ protein can induce expression of BAFF (Fig. 4) and increased levels of p202 protein in B6.Nba2-ABC immune cells were associated with increased levels of BAFF (Fig. 5) suggest that p202 protein contributes to defects in B cell apoptosis, splenomegaly, and the ANA phenotype in part through an up-regulation of BAFF expression.

It is known that Fc $\gamma$ RIIB-deficiency in mice on certain genetic background increases expression of type I IFN and BAFF [43]. However, type I IFN-treatment of immune cells or increased levels of the p202 protein in immune cells suppress expression of the Fc $\gamma$ RIIB receptor [31]. Given that BAFF-transgenic mice manifest increases in peritoneal B1 cells, which express reduced levels of the Fc $\gamma$ RIIB, our observations that BAFF up-regulates expression of p202 protein (Fig. 6) raise the possibility that BAFF down-regulates expression of Fc $\gamma$ RIIB in part through up-regulation of p202 protein. Further studies are needed to test this possibility.

The 5'-regulatory region $(\sim 2.0 \mathrm{~Kb})$ of the murine Tnfsf13b (BAFF gene) gene, which is present in the BAFF-luc-reporter, contains NF- $\mathrm{kB}$-responsive elements [39]. Moreover, transcription of murine BAFF gene is activated by treatment of macrophage cells with TLR4 ligand LPS through activation of NF- $\kappa B$ [44]. Because increased levels of p202 protein in dendritic cells activate the transcriptional activity of NF- $\mathrm{kB}$ [45], it is conceivable that increased levels of p202 in murine macrophage cell line RAW264.7 stimulate the expression of BAFF through activation of NF- $\mathrm{xB}$. However, our observations do not rule out additional transcription factors, such as ERa, IRF5 and STAT1, in the regulation of murine BAFF gene. Therefore, further work is in progress to identify the molecular mechanisms. 
Expression of p202 is induced by activation of TLR3, 4, and 9-induced signaling in bone marrow-derived macrophages and macrophage cell lines [46]. Therefore, our observations that increased levels of the p202 protein induced expression of BAFF (Fig. 4) in RAW264.7 cells are consistent with the previous observations that TLR ligands can induce the expression of BAFF in macrophages and monocytes [47].

Increased levels of BAFF are known to induce expression of AID, which is required for class-switch recombination (CSR) for the production of high affinity autoantibodies [48]. Given that expression of AID is also stimulated by the female sex hormone estrogen [49], our observations that estrogen-inducible p202 protein can induce the expression of BAFF make it likely that the p202 protein promotes CSR in part through up-regulation of BAFF expression.

Expression of Ifi202 gene is induced by IL-6 through STAT3 activation [50]. Given that BAFF-induced signaling in cells can up-regulate expression of IL-6 in human monocytes [51], our observations that BAFF can induce expression of p202 (Fig. 6) support the possibility that BAFF-IL-6 axis regulates expression of p202 in immune cells.

In summary, our observations demonstrate that levels of murine BAFF are up-regulated by activation of estrogen and IFN-signaling in immune cells through up-regulation of p202 protein (Fig. 7). However, it remains to be seen whether the activation of these signaling pathways contributes to a gender bias in increased expression of human BAFF in SLE patients. To the best of our knowledge, the signaling pathways that contribute to a sex bias in the expression of murine BAFF have not been identified previously. Consequently, our observations will serve basis to identify the molecular mechanisms through which estrogen and IFN-signaling collaborate to up-regulate expression of human BAFF. Understanding the molecular mechanisms that contribute to increased expression of human BAFF is critical to effectively treat SLE patients.

\section{Acknowledgments}

We thank Drs. Karen Gould, Paula Pitha, Katherine Fitzgerald, and Lauren Erickson for providing reagents and helpful discussions. This work was supported by grants from the NIH (AI026066 and AI089775) to D.C.

\section{References}

1. Kotzin BL. Systemic lupus erythematosus. Cell. 1996; 85(3):303-306. [PubMed: 8616885]

2. Tsokos GC. Systemic lupus erythematosus. N Engl J Med. 2011; 365(22):2110-2121. [PubMed: 22129255]

3. Whitacre CC. Sex differences in autoimmune disease. Nat Immunol. 2001; 2(9):777-780. [PubMed: 11526384]

4. Cohen-Solal JF, Jeganathan V, Hill L, Kawabata D, Rodriguez-Pinto D, Grimaldi C, et al. Hormonal regulation of B-cell function and systemic lupus erythematosus. Lupus. 2008; 17(6):528532. [PubMed: 18539705]

5. Pennell LM, Galligan CL, Fish EN. Sex affects immunity. J Autoimmun. 2012; 38(2-3):J282-J291. [PubMed: 22225601]

6. Salloum R, Niewold TB. Interferon regulatory factors in human lupus pathogenesis. Transl Res. 2011; 157(6):326-331. [PubMed: 21575916]

7. Moore PA, Belvedere O, Orr A, Pieri K, LaFleur DW, Feng P, et al. BLyS: member of the tumor necrosis factor family and B lymphocyte stimulator. Science. 1999; 285(5425):260-263. [PubMed: 10398604]

8. Mackay F, Schneider P, Rennert P, Browning J. BAFF AND APRIL: a tutorial on B cell survival. Annu Rev Immunol. 2003; 21:231-264. [PubMed: 12427767] 
9. Mackay F, Schneider P. Cracking the BAFF code. Nat Rev Immunol. 2009; 9(7):491-502. [PubMed: 19521398]

10. Ohata J, Zvaifler NJ, Nishio M, Boyle DL, Kalled SL, Carson DA, et al. Fibroblast-like synoviocytes of mesenchymal origin express functional B cell-activating factor of the TNF family in response to proinflammatory cytokines. J Immunol. 2005; 174(2):864-870. [PubMed: 15634908]

11. Ittah M, Miceli-Richard C, Eric Gottenberg J, Lavie F, Lazure T, Ba N, et al. B cell-activating factor of the tumor necrosis factor family (BAFF) is expressed under stimulation by interferon in salivary gland epithelial cells in primary Sjögren's syndrome. Arthritis Res Ther. 2006; 8(2):R51. [PubMed: 16507175]

12. Kato A, Truong-Tran AQ, Scott AL, Matsumoto K, Schleimer RP. Airway epithelial cells produce B cell-activating factor of TNF family by an IFN- $\beta$-dependent mechanism. J Immunol. 2006; 177(10):7164-7172. [PubMed: 17082634]

13. Rickert RC, Jellusova J, Miletic AV. Signaling by the tumor necrosis factor receptor superfamily in B-cell biology and disease. Immunol Rev. 2011; 244(1):115-133. [PubMed: 22017435]

14. Schiemann B, Gommerman JL, Vora K, Cachero TG, Shulga-Morskaya S, Dobles M, et al. An essential role for BAFF in the normal development of B cells through a BCMA-independent pathway. Science. 2001; 293(5537):2111-2114. [PubMed: 11509691]

15. Mackay F, Woodcock SA, Lawton P, Ambrose C, Baetscher M, Schneider P, et al. Mice transgenic for BAFF develop lymphocytic disorders along with autoimmune manifestations. J Exp Med. 1999; 190(11):1697-1710. [PubMed: 10587360]

16. Groom J, Kalled SL, Cutler AH, Olson C, Woodcock SA, Schneider P, et al. Association of BAFF/ BLyS overexpression and altered B cell differentiation with Sjögren's syndrome. J Clin Invest. 2002; 109(1):59-68. [PubMed: 11781351]

17. Liu Z, Bethunaickan R, Huang W, Ramanujam M, Madaio MP, Davidson A. IFN-a confers resistance of systemic lupus erythematosus nephritis to therapy in NZB/W F1 mice. J Immunol. 2011; 187(3):1506-1513. [PubMed: 21705616]

18. Becker-Merok A, Nikolaisen C, Nossent HC. B-lymphocyte activating factor in systemic lupus erythematosus and rheumatoid arthritis in relation to autoantibody levels, disease measures and time. Lupus. 2006; 15(9):570-576. [PubMed: 17080911]

19. Manzi S, Sánchez-Guerrero J, Merrill JT, Furie R, Gladman D, Navarra SV, et al. Effects of belimumab, a B lymphocyte stimulator-specific inhibitor, on disease activity across multiple organ domains in patients with systemic lupus erythematosus: combined results from two phase III trials. Ann Rheum Dis. 2012 May 1. Epub ahead of print.

20. Theofilopoulos AN, Dixon FJ. Murine models of systemic lupus erythematosus. Adv Immunol. 1985; 37:269-290. [PubMed: 3890479]

21. Mohan C. Murine lupus genetics: lessons learned. Curr Opin Rheumatol. 2001; 13(5):352-360. [PubMed: 11604588]

22. Rozzo SJ, Allard JD, Choubey D, Vyse TJ, Izui S, Peltz G, et al. Evidence for an interferoninducible gene, Ifi202, in the susceptibility to systemic lupus. Immunity. 2001; 15(3):435-443. [PubMed: 11567633]

23. Gubbels MR, Jørgensen TN, Metzger TE, Menze K, Steele H, Flannery SA, et al. Effects of MHC and gender on lupus-like autoimmunity in Nba2 congenic mice. J Immunol. 2005; 175(9):61906196. [PubMed: 16237116]

24. Jørgensen TN, Roper E, Thurman JM, Marrack P, Kotzin BL. Type I interferon signaling is involved in the spontaneous development of lupus-like disease in B6.Nba2 and (B6.Nba2 $\mathrm{X}$ NZW)F(1) mice. Genes Immun. 2007; 8(8):653-662. [PubMed: 17882225]

25. Choubey D, Kotzin BL. Interferon-inducible p202 in the susceptibility to systemic lupus. Front Biosci. 2002; 7:e252-e262. [PubMed: 11991834]

26. Choubey D, Panchanathan R. Interferon-inducible Ifi200-family genes in systemic lupus erythematosus. Immunol Lett. 2008; 119(1-2):32-41. [PubMed: 18598717]

27. Choubey D, Panchanathan R, Duan X, Liu H, Liu H. Emerging roles for the interferon-inducible p200-family proteins in sex bias in systemic lupus erythematosus. J Interferon Cytokine Res. 2011; 31(12):893-906. [PubMed: 21902548] 
28. Jørgensen TN, Alfaro J, Enriquez HL, Jiang C, Loo WM, Atencio S, et al. Development of murine lupus involves the combined genetic contribution of the SLAM and FcgammaR intervals within the Nba2 autoimmune susceptibility locus. J Immunol. 2010; 184(2):775-786. [PubMed: 20018631]

29. Boross P, Arandhara VL, Martin-Ramirez J, Santiago-Raber ML, Carlucci F, Flierman R, et al. The inhibiting Fc receptor for IgG, Fc $\gamma$ RIIB, is a modifier of autoimmune susceptibility. $\mathrm{J}$ Immunol. 2011; 187(3):1304-1313. [PubMed: 21724994]

30. Choubey D, Panchanathan R, Liu H. Comment on "The inhibiting Fc receptor for IgG, FcgammaRIIB, is a modifier of autoimmune susceptibility". J Immunol. 2011; 187(8):3909. [PubMed: 21969314]

31. Panchanathan R, Shen H, Duan X, Rathinam VA, Erickson LD, Fitzgerald KA, et al. Aim2deficiency in mice suppresses the expression of the inhibitory Fcgamma receptor (FcgammaRIIB) through the induction of the IFN-inducible p202, a lupus susceptibility protein. J Immunol. 2011; 186(12):6762-6770. [PubMed: 21551362]

32. Panchanathan R, Shen H, Bupp MG, Gould KA, Choubey D. Female and male sex hormones differentially regulate expression of Ifi202, an interferon-inducible lupus susceptibility gene within the Nba2 interval. J Immunol. 2009; 183(11):7031-7038. [PubMed: 19890043]

33. Gribaudo G, Toniato E, Engel DA, Lengyel P. Interferons as gene activators. Characteristics of an interferon-activatable enhancer. J Biol Chem. 1987; 262(24):11878-11883. [PubMed: 3624238]

34. Krumbholz M, Faber H, Steinmeyer F, Hoffmann LA, Kümpfel T, Pellkofer H, et al. Interferonbeta increases BAFF levels in multiple sclerosis: implications for B cell autoimmunity. Brain. 2008; 131(Pt 6):1455-1463. [PubMed: 18474519]

35. Harigai M, Kawamoto M, Hara M, Kubota T, Kamatani N, Miyasaka N. Excessive production of IFN-gamma in patients with systemic lupus erythematosus and its contribution to induction of $\mathrm{B}$ lymphocyte stimulator/B cell-activating factor/TNF ligand superfamily-13B. J Immunol. 2008; 181(3):2211-2219. [PubMed: 18641361]

36. Venkatesh J, Yoshifuji H, Kawabata D, Chinnasamy P, Stanevsky A, Grimaldi CM, et al. Antigen is required for maturation and activation of pathogenic anti-DNA antibodies and systemic inflammation. J Immunol. 2011; 186(9):5304-5312. [PubMed: 21444762]

37. Panchanathan R, Shen H, Zhang X, Ho SM, Choubey D. Mutually positive regulatory feedback loop between interferons and estrogen receptor-alpha in mice: implications for sex bias in autoimmunity. PLoS One. 2010; 5(5):e10868. [PubMed: 20526365]

38. Panchanathan R, Liu H, Liu H, Fang CM, Erickson LD, Pitha PM, et al. Distinct regulation of murine lupus susceptibility genes by the IRF5/Blimp-1 axis. J Immunol. 2012; 188(1):270-278. [PubMed: 22116829]

39. Kim HA, Jeon SH, Seo GY, Park JB, Kim PH. TGF-beta1 and IFN-gamma stimulate mouse macrophages to express BAFF via different signaling pathways. J Leukoc Biol. 2008; 83(6):14311439. [PubMed: 18334541]

40. Theofilopoulos AN, Balderas RS, Shawler DL, Lee S, Dixon FJ. Influence of thymic genotype on the systemic lupus erythematosus-like disease and T cell proliferation of MRL/Mp-lpr/lpr mice. J Exp Med. 1981; 153(6):1405-1414. [PubMed: 6972998]

41. Panchanathan R, Duan X, Shen H, Rathinam VA, Erickson LD, Fitzgerald KA, et al. Aim2 deficiency stimulates the expression of IFN-inducible Ifi202, a lupus susceptibility murine gene within the Nba2 autoimmune susceptibility locus. J Immunol. 2010; 185(12):7385-7393. [PubMed: 21057088]

42. Bynoté KK, Hackenberg JM, Korach KS, Lubahn DB, Lane PH, Gould KA. Estrogen receptoralpha deficiency attenuates autoimmune disease in $(\mathrm{NZB} \times \mathrm{NZW}) \mathrm{F}_{1}$ mice. Genes Immun. 2008; 9(2):137-152. [PubMed: 18200028]

43. Amezcua Vesely MC, Schwartz M, Bermejo DA, Montes CL, Cautivo KM, Kalergis AM, et al. Fc $\gamma$ RIIb and BAFF Differentially Regulate Peritoneal B1 Cell Survival. J Immunol. 2012 Apr 18. Epub ahead of print.

44. Moon EY, Park H. B cell activating factor (BAFF) gene promoter activity depends upon coactivator, p300. Immunobiology. 2007; 212(8):637-645. [PubMed: 17869641] 
45. Yamauchi M, Hashimoto M, Ichiyama K, Yoshida R, Hanada T, Muta T, Komune S, Kobayashi T, Yoshimura A. Ifi202, an IFN-inducible candidate gene for lupus susceptibility in NZB/W F1 mice, is a positive regulator for NF-kappaB activation in dendritic cells. Int Immunol. 2007; 19(8):935942. [PubMed: 17702989]

46. Panchanathan R, Duan X, Arumugam M, Shen H, Liu H, Choubey D. Cell type and genderdependent differential regulation of the $\mathrm{p} 202$ and Aim 2 proteins: implications for the regulation of innate immune responses in SLE. Mol Immunol. 2011; 49(1-2):273-280. [PubMed: 21943709]

47. Yamada T, Lizhong S, Takahashi N, Kubo S, Narita N, Suzuki D, et al. Poly(I:C) induces BLySexpression of airway fibroblasts through phosphatidylinositol 3-kinase. Cytokine. 2010; 50(2): 163-169. [PubMed: 20089415]

48. Kim HA, Seo GY, Kim PH. Macrophage-derived BAFF induces AID expression through the p38MAPK/CREB and JNK/AP-1 pathways. J Leukoc Biol. 2011; 89(3):393-398. [PubMed: 21169521]

49. Pauklin S, Sernández IV, Bachmann G, Ramiro AR, Petersen-Mahrt SK. Estrogen directly activates AID transcription and function. J Exp Med. 2009; 206(1):99-111. [PubMed: 19139166]

50. Pramanik R, Jørgensen TN, Xin H, Kotzin BL, Choubey D. Interleukin-6 induces expression of Ifi202, an interferon-inducible candidate gene for lupus susceptibility. J Biol Chem. 2004; 279(16):16121-16127. [PubMed: 14764608]

51. Yoshimoto K, Tanaka M, Kojima M, Setoyama Y, Kameda H, Suzuki K, et al. Regulatory mechanisms for the production of BAFF and IL- 6 are impaired in monocytes of patients of primary Sjögren's syndrome. Arthritis Res Ther. 2011; 13(5):R170. [PubMed: 22018243] 


\section{Highlights}

$>\quad$ Murine BAFF expression is up-regulated by estrogen and interferon

$>\quad$ Expression of murine BAFF depends on ERa, IRF5, and STAT1

$>\quad$ Increased expression of p202 protein up-regulates BAFF expression

$>\quad$ Increased levels of p202 in lupus-prone mice are associated with increased levels of BAFF

$>\quad$ Studies identify p202 as a regulator of murine BAFF 

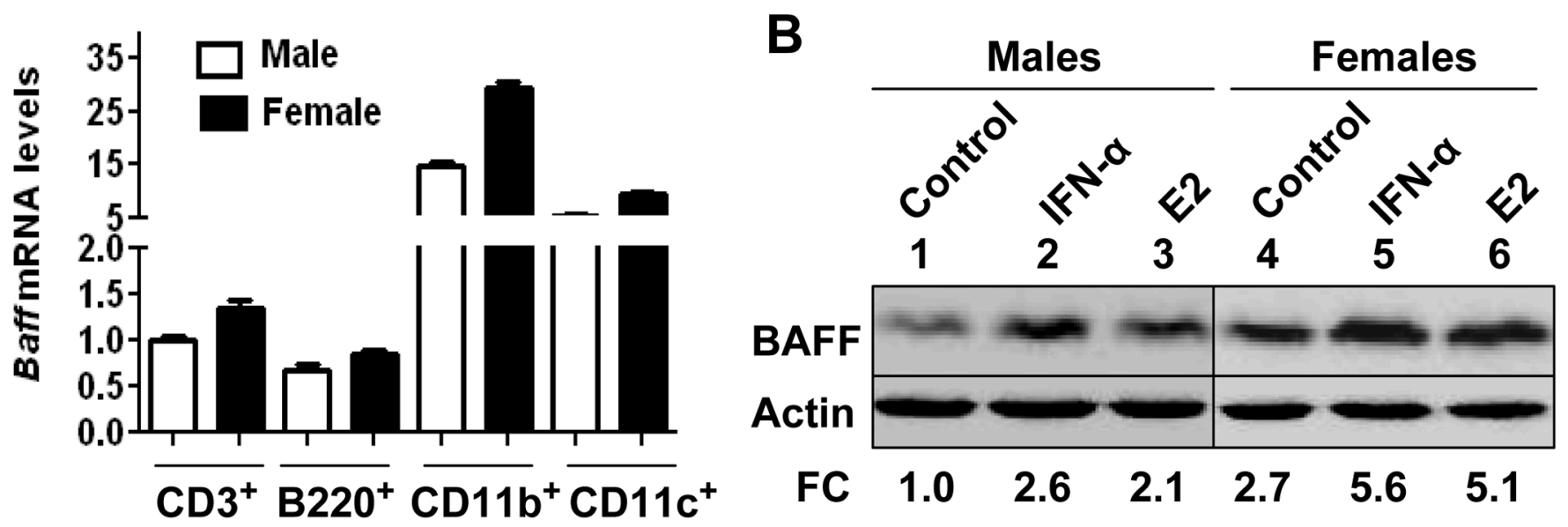

C
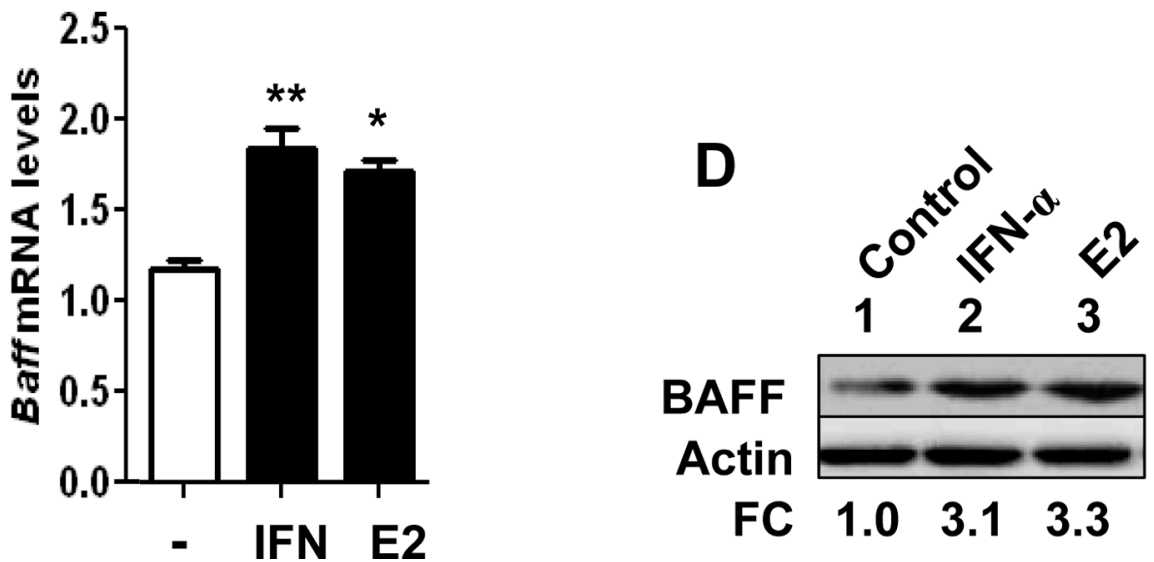

Fig. 1. Gender, sex hormone estrogen, and IFN regulate BAFF mRNA levels A. Total RNA prepared from the indicated purified cells isolated from C57BL/6 males and age-matched females was analyzed by quantitative real-time PCR using TaqMan assays specific to the murine BAFF gene. The ratio of the BAFF mRNA levels to $\beta 2$-microglobulin mRNA was calculated in units (one unit being the ratio of the BAFF mRNA to $\beta 2$ -

microglobulin mRNA). The ratio of mRNA levels in $\mathrm{CD}^{+}$cells from male mice is indicated as 1 . The error bars represent the standard deviation $(* p<0.05 ; * * p<0.01)$.

B. Purified CD $11 b^{+}$cells isolated from C57BL/6 males and age-matched female mice were either left untreated (lanes 1 and 4) or treated with estrogen (10 nM; lanes 2 and 5) or IFN-a $(1,000 \mathrm{u} / \mathrm{ml}$; lanes 3 and 6$)$ for $14 \mathrm{~h}$. After the treatment, total cel lysates containing equal amounts of proteins were subjected to immunoblotting using antibodies specific to the indicated proteins. Fold change (FC) in levels of BAFF protein is indicated.

C. Purified B220 ${ }^{+}$cells isolated from C57BL/ 6 females mice were either left untreated or treated with IFN-a $(1,000 \mathrm{u} / \mathrm{ml})$ or estrogen $(10 \mathrm{nM})$ for $14 \mathrm{~h}$. Total RNA was analyzed by quantitative real-time PCR using TaqMan assays as described in panel A. The ratio of mRNA levels in untreated cells from is indicated as 1 . The error bars represent the standard deviation. 
D. Purified B220 ${ }^{+}$cells isolated from C57BL/6 females mice were either left untreated or treated with IFN-a $(1,000 \mathrm{u} / \mathrm{ml})$ or estrogen $(10 \mathrm{nM})$ for $14 \mathrm{~h}$. Total cell lysates containing equal amounts of proteins were analyzed by immunoblotting. Fold change in BAFF protein levels is indicated. 


\section{A}

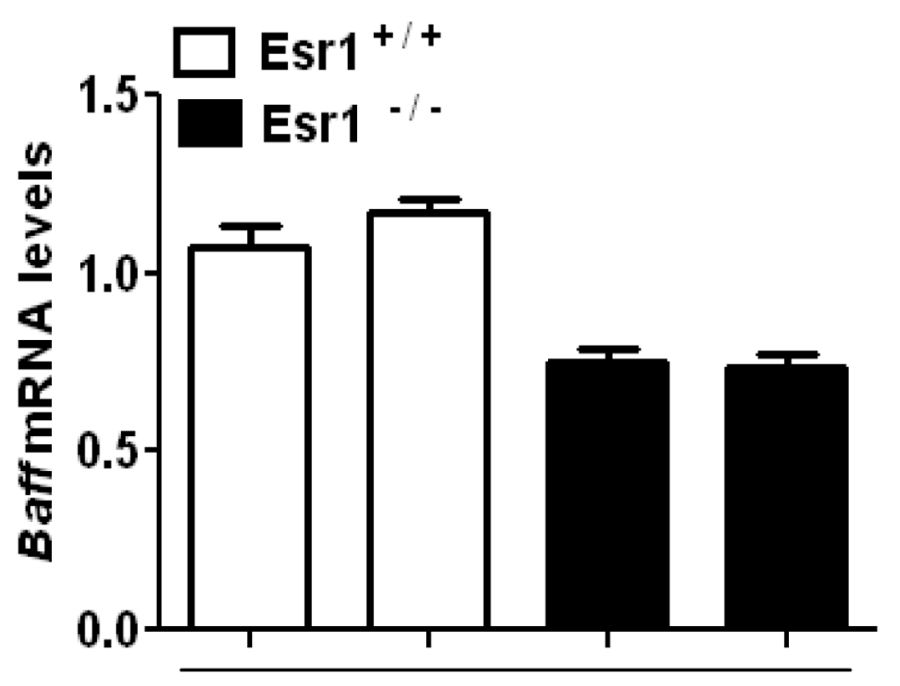

Females

Fig. 2. BAFF expression depends on ERa, IRF5, and STAT1 the standard deviation. proteins.

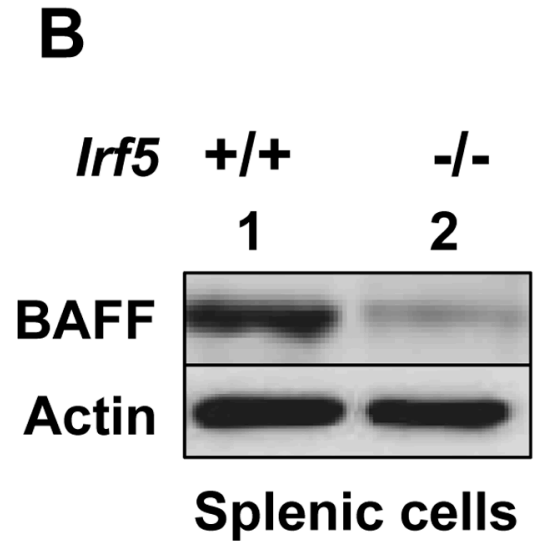

D

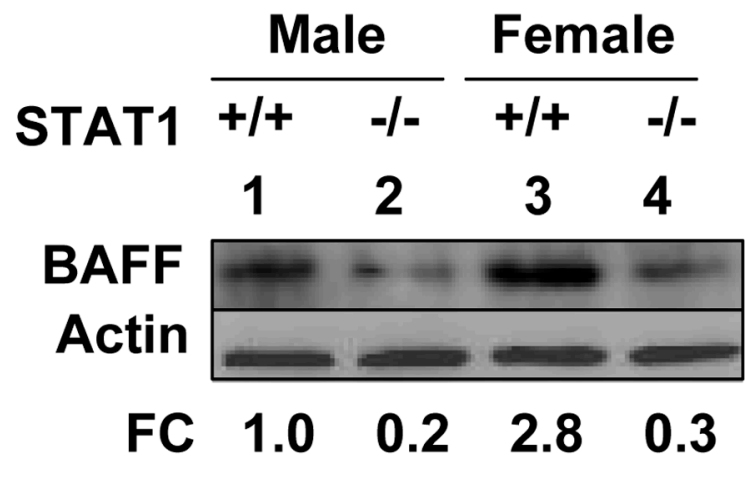

A. Total RNA preparations from splenic cells isolated from wild type or age-matched Esr1deficient female mice were subjected to quantitative real-time PCR. The ratio of the BAFF mRNA levels to $\beta 2$-microglobulin mRNA was calculated in units. The error bars represent

B. Total cell lysates from splenic cells isolated from wild type or age-matched Irf5-deficient female mice were subjected to immunoblotting using antibodies specific to the indicated

C. Total RNA preparations from splenic cells isolated from wild type or age-matched Stat1deficient mice were subjected to quantitative real-time PCR. The ratio of the BAFF mRNA levels to $\beta 2$-microglobulin mRNA was calculated in units. The ratio of mRNA levels in 
splenic cells from wild type male mice is indicated as 1 .The error bars represent the standard deviation.

D. Total cell lysates from splenic cells isolated from wild type or age-matched Stat1deficient mice were subjected to immunoblotting. Fold change in BAFF protein levels is indicated. 
A

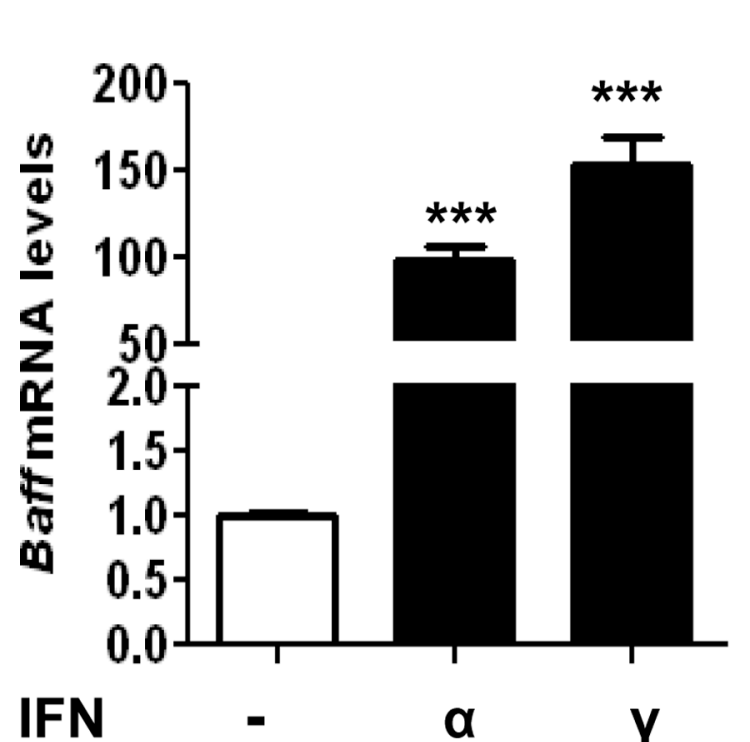

B

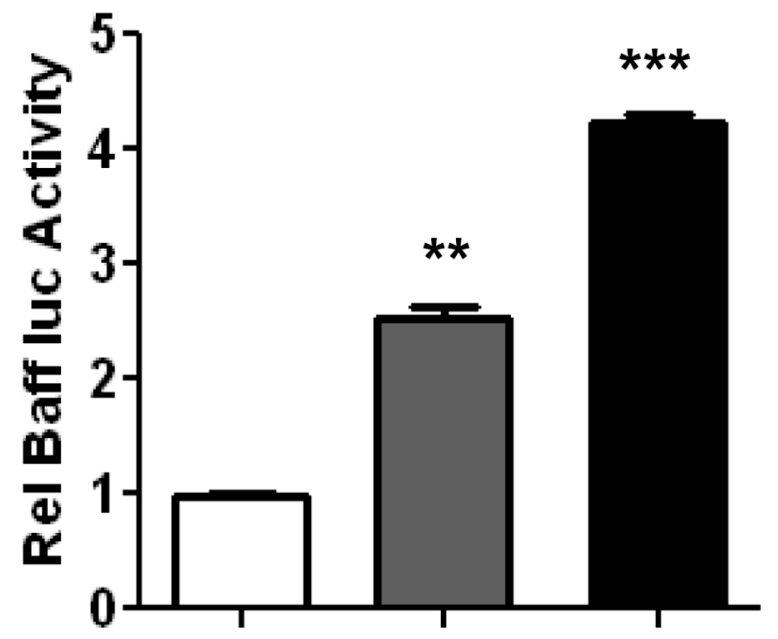

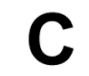

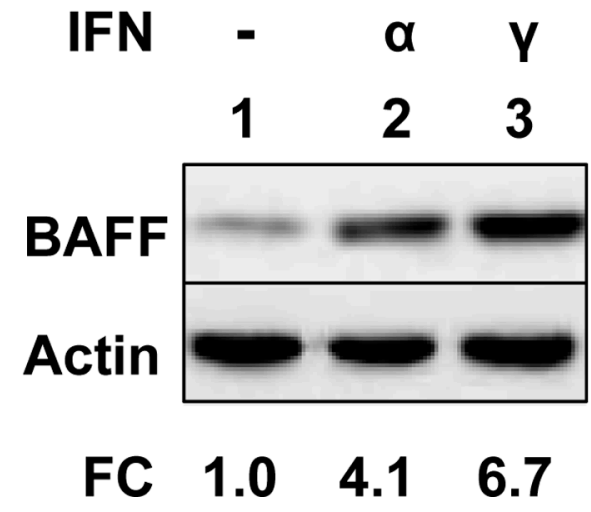

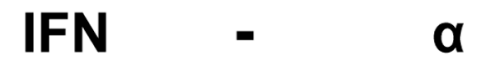

D

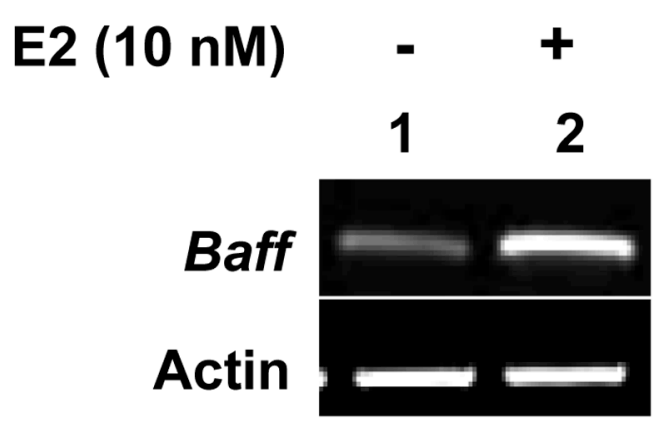

Fig. 3. Treatment of RAW264.7 cells with IFNs or estrogen increases BAFF expression A. Sub-confluent cultures of RAW264.7 cells were either left untreated or treated with IFN$a$ or IFN- $\gamma$ for $14 \mathrm{~h}$. After the treatments, total RNA was prepared and subjected to quantitative real-time PCR to analyze BAFF mRNA levels. The ratio of the BAFF mRNA levels to $\beta 2$-microglobulin mRNA was calculated in units. The ratio of mRNA levels in splenic cells from control cells is indicated as 1 .The error bars represent the standard deviation $(* * * p<0.001)$.

B. Sub-confluent cultures of RAW264.7 cells were transfected with BAFF-luc-reporter (1.8 $\mu \mathrm{g})$ plus pRL-TK plasmid $(0.2 \mu \mathrm{g}) .24 \mathrm{~h}$ after transfections, the transfected cells were either left untreated or treated with the indicated IFN for $16 \mathrm{~h}$. After the treatments cells were lysed and cell lysates were analyzed for dual luciferase activity. The ratio between firefly 
luciferase and Renilla luciferase in control cells is indicated as 1 . The error bars represent the standard deviation $(* * p<0.01 ; * * * p<0.001)$.

C. Sub-confluent cultures of RAW264.7 cells were either left untreated or treated with IFN$a$ or IFN- $\gamma$ for $14 \mathrm{~h}$. After the treatments, total cell lysates were analyzed by immunoblotting. Fold change in BAFF protein levels is indicated.

D. Sub-confluent cultures of RAW264.7 cells were either left untreated or treated with E2 $(10 \mathrm{nM})$ for $24 \mathrm{~h}$. After the treatment, total RNA was prepared and subjected to semiquantitative PCR to analyze BAFF and actin mRNA levels. 


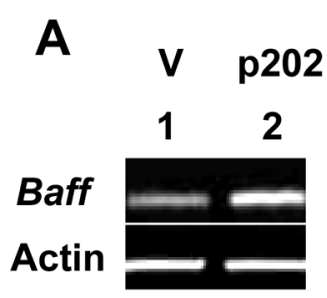

FC $\quad 1.0 \quad 3.8$

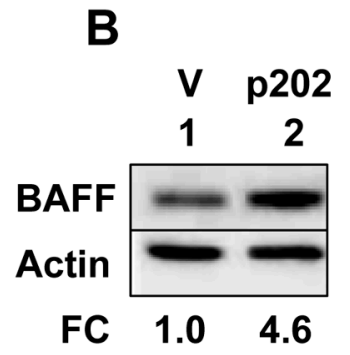

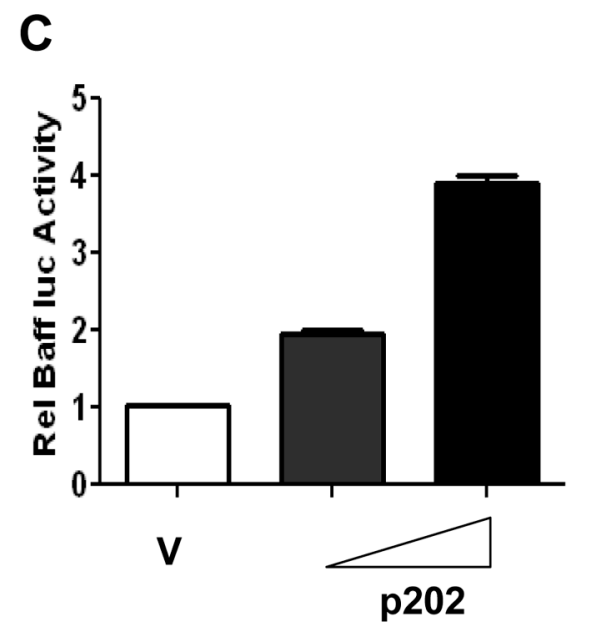

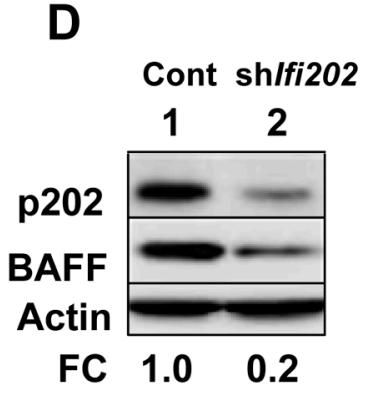

Fig. 4. p202 protein regulates BAFF expression

A. Total RNA prepared from RAW264.7 cells stably transfected with vector (V; pCMV) or pCMV-202 (p202) were analyzed by semi-quantitative PCR. Fold change in BAFF mRNA levels is indicated.

B. Total cell extracts prepared from RAW264.7 cells stably transfected with vector (V; pCMV) or pCMV-202 (p202) were analyzed by immunoblotting. Fold change in BAFF protein levels is indicated.

C. Sub-confluent cultures of RAW264.7 cells were transfected with BAFF-luc-reporter (1 $\mu \mathrm{g})$ and pRL-TK plasmid $(0.2 \mu \mathrm{g})$ along with pCMV plasmid (V; $0.4 \mu \mathrm{g})$ or pCMV-202 plasmid (p202; 0.2 or $0.4 \mu \mathrm{g}$ ). $45 \mathrm{~h}$ after transfections, cells were lysed and cell lysates were analyzed for dual luciferase activity. The ratio between firefly luciferase and Renilla luciferase in vector transfected cells is indicated as 1 . The error bars represent the standard deviation.

D. Total cell extracts prepared from J774.A1 cells stably infected with control lentivirus (Cont) or shIfi202 lentivirus were analyzed by immunoblotting. Fold change in BAFF protein levels is indicated. 

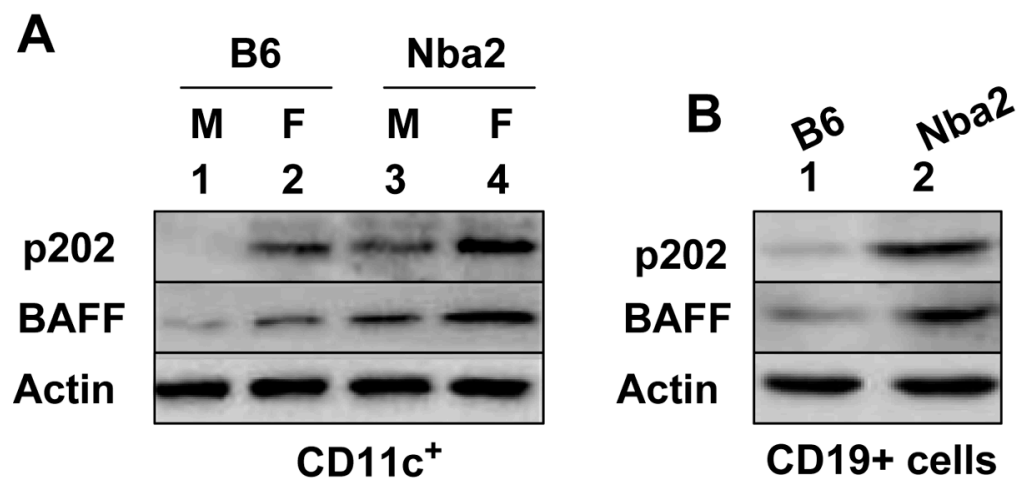

\section{C}

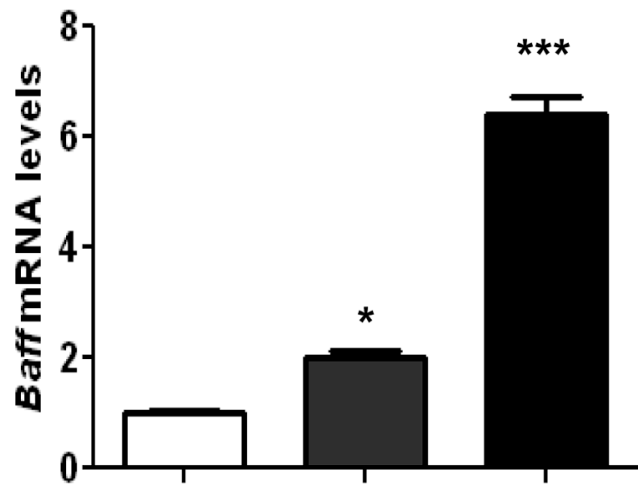

B6 Nba2-C Nba2
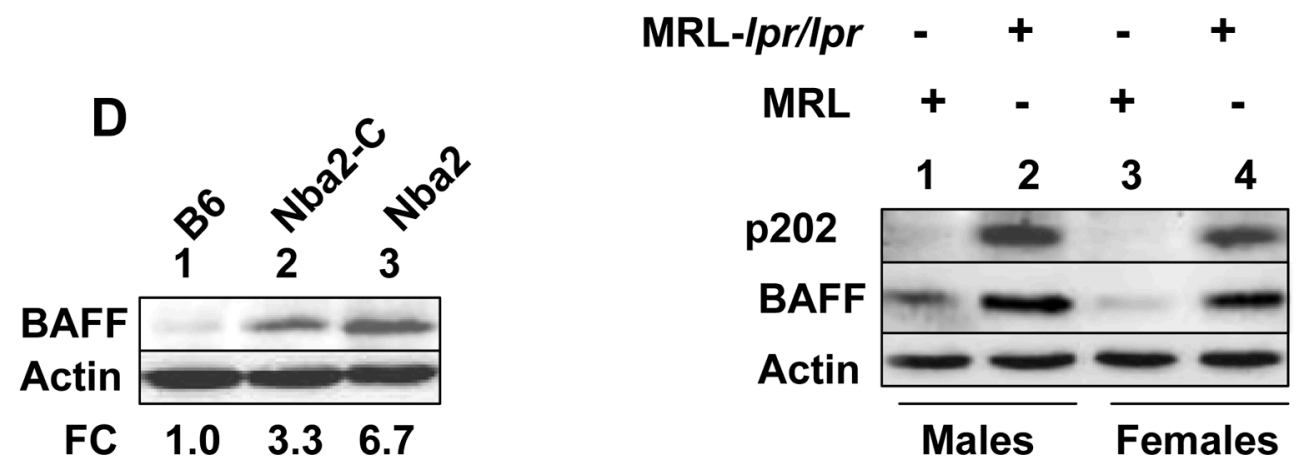

Fig. 5. Increased levels of p202 protein in lupus-prone mice are associated with increased expression levels of BAFF

A. Total cell extracts prepared from purified CD11c ${ }^{+}$cells isolated from C57BL/6 (B6) or B6. Nba2 (Nba2) male and age-matched female mice were analyzed by immunoblotting using antibodies specific to the indicated proteins.

B. Total cell extracts prepared from purified CD19+ cells isolated from B6 or B6. Nba2 (Nba2) female mice were analyzed by immunoblotting using antibodies specific to the indicated proteins.

C. Total RNA prepared from splenic cells isolated from age-matched C57BL/6 (B6), B6.Nba2-C (C), or B6.Nb2 (Nba2) females was analyzed by quantitative real-time PCR using TaqMan assays specific to the murine BAFF gene. The ratio of the BAFF mRNA levels to $\beta 2$-microglobulin mRNA was calculated in units (one unit being the ratio of the BAFF mRNA to $\beta 2$-microglobulin mRNA). The ratio of mRNA levels in the B6 splenic cells is indicated as 1 . The error bars represent the standard deviation $(* p<0.05$;

$* * * p<0.001)$.

D. Purified CD19+ cells from age-matched B6, B6.Nba2-C (C), or B6. $\mathrm{Nb2}$ (Nba2) female mice were lysed and the cell lysates were analyzed by immunoblotting. Fold change in BAFF protein levels is indicated.

E. Total splenic cell extracts from wild type MRL or MRL-Ipr/Ipr male and age-matched female mice were analyzed by immunoblotting. 


\section{Male}

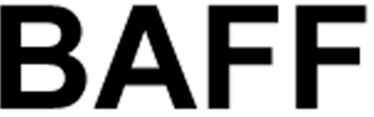

ERa<smiles>[R20][R20]</smiles>

Aim2

Actin
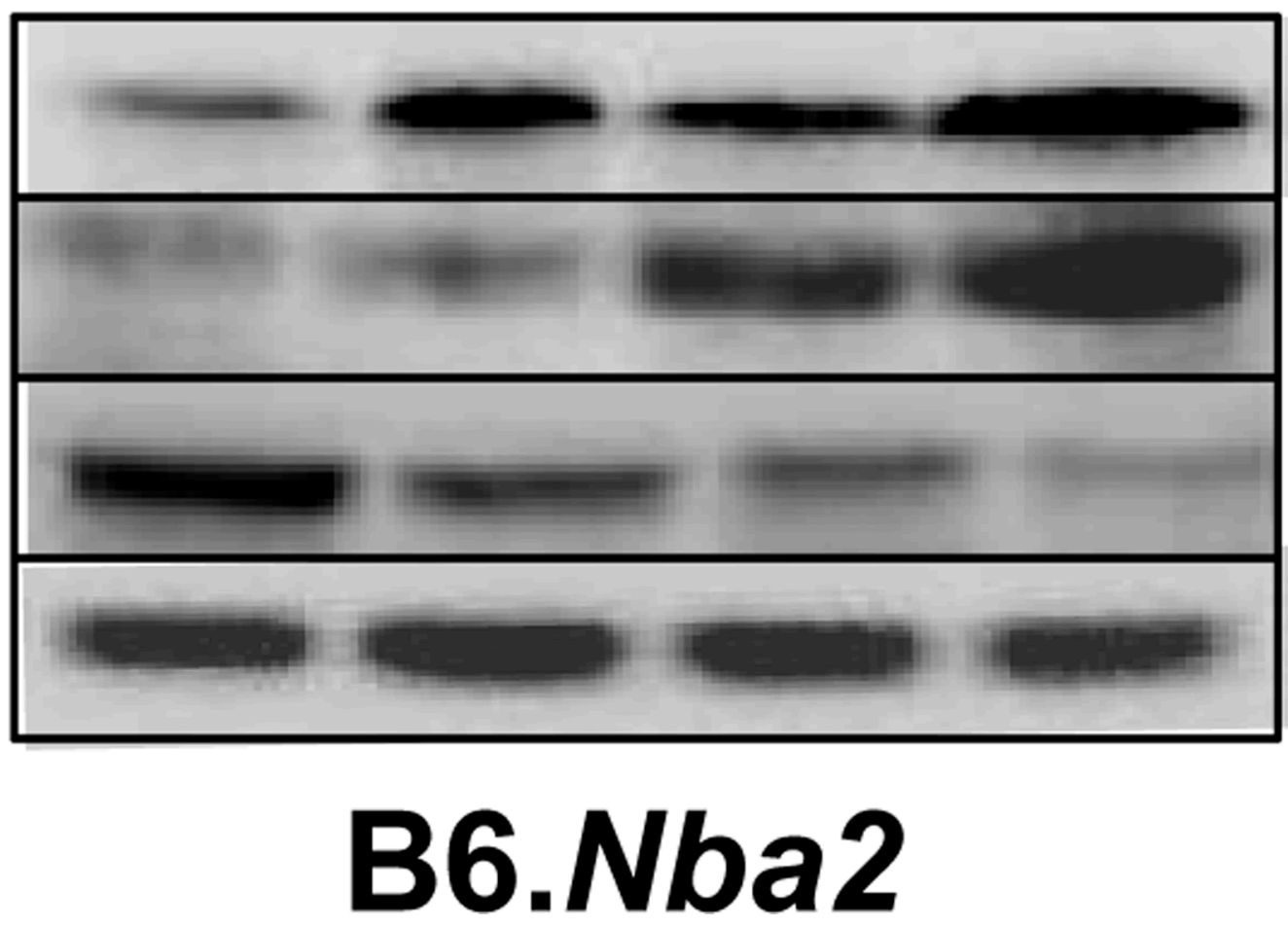

Fig. 6. Treatment of cells with BAFF increases expression levels of p202

Purified splenic $\mathrm{B} 220^{+}$cells isolated from B6.Nba2-ABC male or female mice were either left untreated or treated with recombinant murine BAFF $(10 \mathrm{ng} / \mathrm{ml})$ for $16 \mathrm{~h}$. After the treatment, cell extracts were analyzed by immunoblotting for the indicated proteins. 

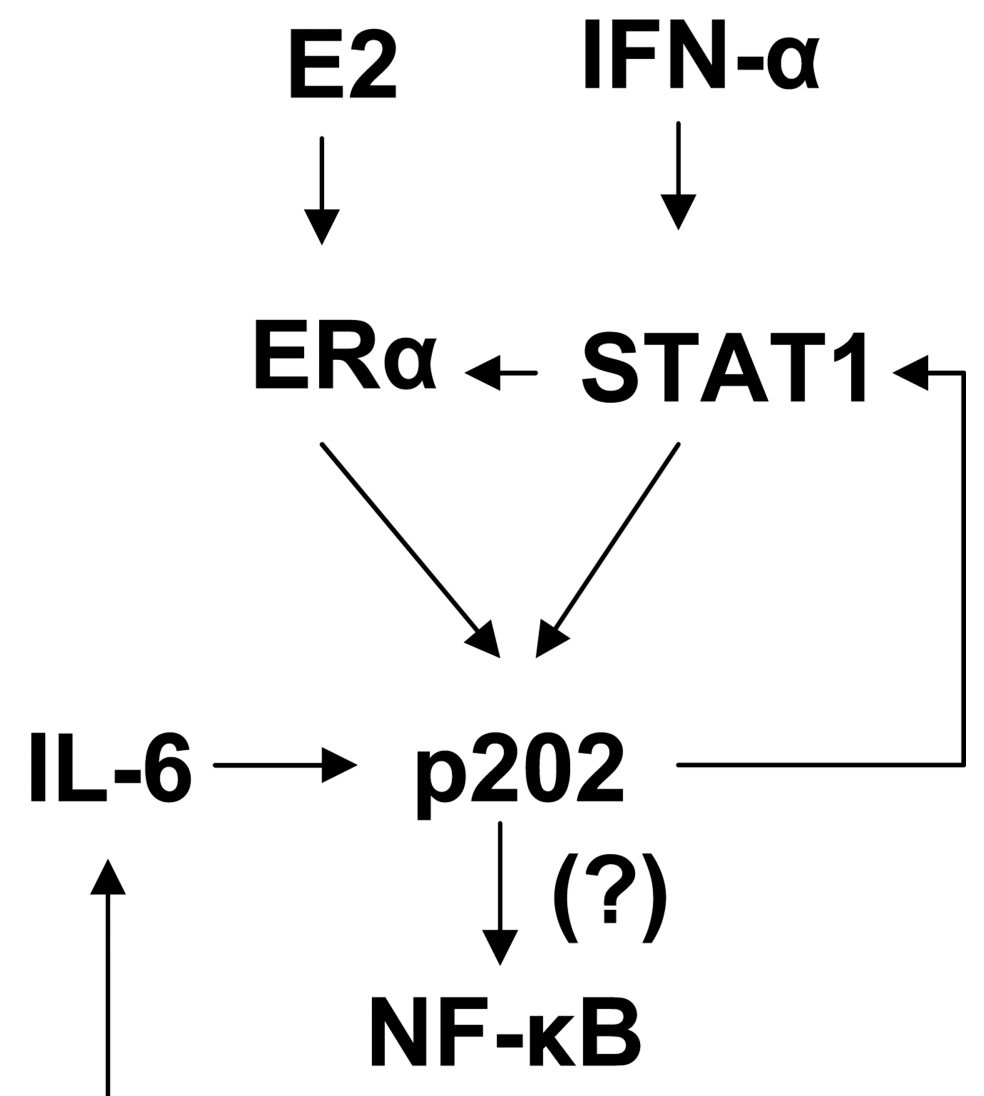

\section{Increased lupus susceptibility}

Fig. 7. Proposed model for the regulation of murine BAFF expression by estrogen and IFNsignaling 